\title{
ISLAMIC PUBLIC EQUITY FUNDS: ENHANCING HALAL SUSTAINABILITY THROUGH MAQASID SHARIAH FRAMEWORK
}

\author{
Wan Nazjmi Mohamed Fisol ${ }^{1}$ \\ Centre for Islamic Finance Education and Research (CIFER), Sultan Abdul Halim Mu'adzam Shah International \\ Islamic University, 09300 Kuala Ketil, Kedah, Malaysia. \\ (Email: wannazjmi@unishams.edu.my) \\ Siti Hafsha Albasri ${ }^{2}$ \\ Centre for Islamic Finance Education and Research (CIFER), Sultan Abdul Halim Mu'adzam Shah International \\ Islamic University, 09300 Kuala Ketil, Kedah, Malaysia. \\ (Email: sitihafsha@unishams.edu.my) \\ Abdulghani Padungraksart ${ }^{3}$ \\ PhD candidate in Islamic Banking \& Finance, Sultan Abdul Halim Mu'adzam Shah International Islamic \\ University, 09300 Kuala Ketil, Kedah, Malaysia. \\ (Email: agp2007@gmail.com)
}

Received date: 09-10-2019

Revised date: 13-10-2019

Accepted date: 15-10-2019

Published date: 10-12-2019

To cite this document: Fisol, W. N. M., Albasri, S. H., \& Padungraksart, A. (2019). Islamic Public Equity Funds: Enahncing Halal Sustainability Through Maqasid Shariah Framework. International Research Journal of Shariah, Muamalat and Islam, 1(2), 11-17.

DOI: 10.35631 irjsmi.12002

\begin{abstract}
Capital market investors in Malaysia have the choice of whether to invest in conventional funds or in Shari'ah compliant funds. However, Islamic law (Shari'ah) is concerned with the moral or ethical value of commercial transactions. Basically, the Muslims are governed by the rules and regulations in respect of halal (permissible) and haram (prohibited). Hence, the objective of the study has been explored the Shari'ah compliant funds products which based on the Maqasid Shari'ah framework due to the five preservations or protections (Protection of Religion, Protection of Life, Protection of Intellect, Protection of Progeny and Protection of wealth). Most of the products offered and developed in Shari'ah compliant public equity funds should be in line with the Maqasid Shari'ah perspective as sustainable of financial planning which bring to the social well-being and impartiality for the public interest (maslahah) by taking into consideration of five preservation, namely the preservation of religion (al-ddin), the preservation of life (al-nafs), the preservation of intellect (al-all), the preservation of progeny (al-nasl) and the preservation of wealth (almal). Therefore, it is important not only in developing Islamic equity funds as a part of industry growing but then beyond that to fulfill the needs of Muslims as well for all the others as well as enhancing halal sustainability through Islamic equity funds product development.
\end{abstract}


Keywords: Islamic Capital market, Public Equity Fund, halal sustainability, Maqasid Shari'ah

\section{Introduction}

Public equity investment is an investment made either through a fund management company or a direct investment made by an investor in the stock market (Al Rafai, 2000). In Malaysia, general public investors usually invest in public equity fund through fund management companies such as Public Equity Fund (Public Bank) or in unit trust management companies such as the Amanah Saham Nasional Berhad (Abdullah, Hassan \& Mohammad, 2007). Public equity fund is suitable for medium to long-term investors who can withstand ups and downs of the stock market in pursuit of capital growth (Abdullah, Hassan \& Mohammad, 2007). Public equity, either conventional or Islamic-based, is an asset class where individuals or organizations can invest or buy ownership in shares/stock of a company directly or through a public market such as the New York Stock Exchange, Kuala Lumpur Stock Exchange and the likes. Public equity differs from private equity in the sense that the equity is offered to public at large to invest.

However, the phenomenal growth of the Islamic financial system globally has undoubtedly provided positive implications on the Islamic investment equity market. In Malaysia, Shari'ah compliant equity funds has emerged very strongly since the last four decades with total funds of around RM150billion (23\%) out of total equity funds of RM674 billion as at end of February 2017 (Securities Commission, May 2017). This is reflected in table 1 below.

Table 1: Overall Positions of ALL Types of Investment Funds in Malaysia (Feb 2017)

\begin{tabular}{|c|c|c|c|c|c|c|}
\hline \multirow[t]{2}{*}{ Sources of funds (in RM billion) } & \multicolumn{3}{|c|}{$\begin{array}{l}\text { Overall (including } \\
\text { Compliant) }\end{array}$} & \multicolumn{3}{|c|}{$\begin{array}{l}\text { Shariah } \\
\text { Equity Funds }\end{array}$} \\
\hline & Local & Foreign & Total & Local & Foreign & Total \\
\hline Unit Trust Funds & 357.64 & 1.17 & 358.81 & 60.86 & 0.79 & 61.65 \\
\hline Wholesale Funds & 90.42 & 0.74 & 91.16 & 35.42 & 0.07 & 35.49 \\
\hline Exchange-traded funds & 1.88 & 0.00 & 1.88 & 0.42 & 0.01 & 0.43 \\
\hline Corporate Bodies & 70.83 & 8.70 & 79.53 & 9.35 & 1.00 & 10.35 \\
\hline Charitable Organizations & 0.50 & 0.44 & 0.94 & 0.17 & 0.00 & 0.17 \\
\hline 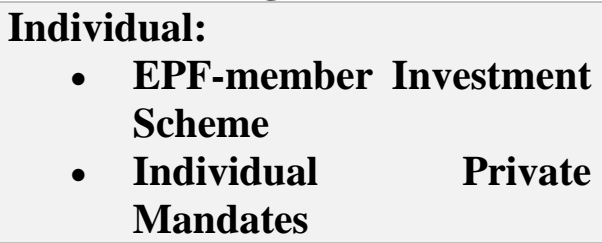 & $\begin{array}{l}0.99 \\
7.92\end{array}$ & $\begin{array}{l}0.00 \\
0.44\end{array}$ & $\begin{array}{l}0.99 \\
8.36\end{array}$ & $\begin{array}{l}0.00 \\
0.06\end{array}$ & $\begin{array}{l}0.00 \\
0.02\end{array}$ & $\begin{array}{l}0.00 \\
0.08\end{array}$ \\
\hline Private Pension Funds & 1.36 & 3.07 & 4.43 & 0.07 & 0.00 & 0.07 \\
\hline Private Retirement Scheme & 1.51 & 0.00 & 1.51 & 0.51 & 0.00 & 0.51 \\
\hline $\begin{array}{l}\text { Statutory Bodies \& } \\
\text { agencies (including EPF) }\end{array}$ & 132.69 & 4.75 & 137.44 & 35.92 & 1.28 & 37.20 \\
\hline Other types of funds & 8.72 & 2.50 & 11.22 & 3.30 & 0.39 & 3.69 \\
\hline Total & 674.46 & 21.81 & 696.27 & 146.08 & 3.56 & 149.64 \\
\hline
\end{tabular}

Source: (https://www.sc.com.my)

However, the phenomenal growth of the Islamic financial system globally has undoubtedly provided positive implications on the Islamic investment equity market. In Malaysia, Shari'ah compliant equity funds has emerged very strongly since the last four decades with 
Malaysian Islamic equity investment indicate that investors may be attracted to equity funds based on fund performance persistence, returns commensurate with market benchmarks, risk mitigation and management style. However, Islamic law (Shari'ah) is governed by the rules and regulations in respect of permissible (halal) and prohibited (haram). For example, Shari'ah prohibits earnings income derived from commercial transaction with elements of interest (riba), uncertainty (gharar) gambling (maysir), production and sale of alcoholic substances, hoarding and deceptive purchases. However, the Muslims are encouraged to participate in commercial transaction in respect of those which Shari'ah principles as well as the objectives of Shariah (Maqasid Shari'ah). (Mohamed Fisol, Md. Radzi, \& Haji-Othman, 2017). Therefore, the purpose of the study is to explore the Shari'ah compliant funds products which based on the Maqasid Shari'ah framework due to the five preservations or protections (Protection of Religion, Protection of Life, Protection of Intellect, Protection of Progeny and Protection of wealth), which in conformity with the Islamic law (Shari'ah) as well as for public interest (maslahah).

\section{Shari'ah Compliant Equity Funds Through the Maqasid Shari'ah Framework}

The fundamental objectives of the Shari 'ah or maqasid al-Shari 'ah are to ensure the wellbeing and welfare of mankind (maslahah; Pl. masalih), both in this world and the hereafter. Maqasid are the key to better understand the Shari 'ah in its true perspective. Imam alGhazali (d. 505 AH/1111 AC) defined maqasid by stressing that the Shari 'ah concerns with preservation of five objectives: "The main objective of the Shari 'ah is to promote the public interest and the well-being of the people, which lies in preservation of their religion (din), their life (nafs), their intellect ('aql), their progeny (nasl) and their wealth (mal). Whatever ensures and covers the safeguarding of these five preservations, and it is a public interest (maslahah), and whatever leaves these five's, it is a harm and against public interest". (AlGhazali, 1998).

\section{Preservation of Religion}

Preservation of religion is an obligatory in the Islamic equity fund characteristic which not led to commit a sin or immorality to Allah SWT. Therefore, it is necessities (daruriyyah) for the Muslim investors to invest in Islamic equity fund, so that it is not misused to cause the user to neglect the remembrance of Allah SWT by avoiding any form of transactions that have elements of usury (riba), uncertainty (gharar) and gambling (maysir). In order to be in line with the preservation of religion, Islamic equity fund characteristic should be increase Religious facilities or tangible attributes such as enhancing the online technology platform of trusted Islamic investing equity fund with increasing the understanding and awareness by Islamic investors as a medium of risk tolerance. The awareness should include that profits earned are not merely gains in this world only, but profits in the hereafter, although the profit of the non-Shari'ah compliant platform more profitable compered to Shari'ah compliant equity funds. It is because the Islamic equity fund needs to be maintained to ensure the continuity of the product is to uphold the religion through faith and piety in investing of the Islamic equity fund products. Allah S.W.T said: "Allah has explained to you - among the matters of religion that He has ordained - as that which He has enjoined on Nuh, and that which We (Allah) have revealed to you (O Muhammad), and that which We have enjoined on Ibrahim, Musa, and Isa. Namely, that ye should remain steadfast in Religion, and make no divisions therein; it is hard for the polytheists (to accept monotheism) to which you call them. Allah chooses to bring to His Religion of Monotheism whom He pleases, and guides to His Religion those who turn to Him (in obedience)". (Al-Quran: Al-Syuura; 42: 13) 
Religious identity appears to play an important role in shaping the intention and choices of Islamic equity fund among Muslim investors. It is a religious obligation for all Muslims to consume products that are allowed by Allah SWT and falls under the authority of Shariah. Meanwhile, Shariah Compliant equity fund products generally refer to all such products accordance with the instructions of Almighty Allah SWT and Prophet Mohammad SAW. In Malaysia, Shari'ah compliant equity funds should be in line with the regulation made by the Security Commission (SC) under Shariah Advisory Committee (SAC). The SAC of SC screens listed shares or equity based on certain methodology. As a preliminary screening, companies which activities are not contrary to Shariah principles will be classified as Shariah compliant securities. On the other hand, companies will be deemed as Shariah non-compliant if they are involved in the following core activities as in table 2.

Table 2: Screening as Shariah Non-Compliant Equity Fund

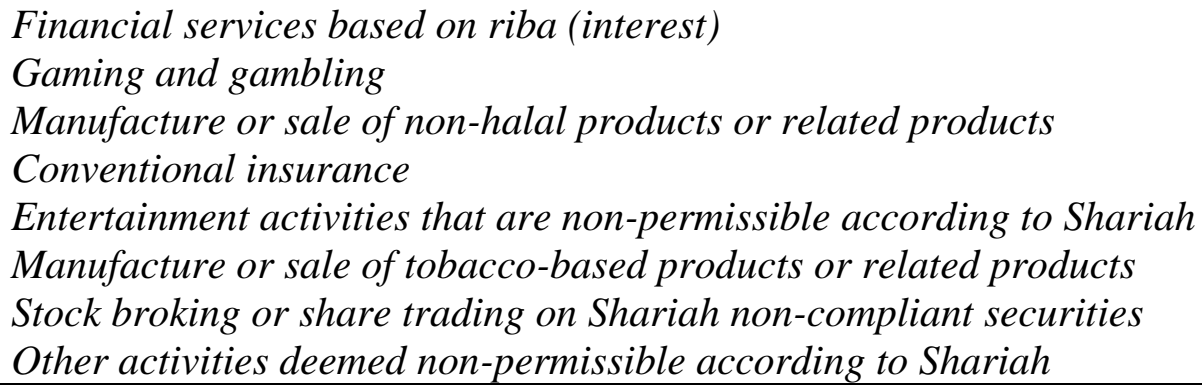

Source: (www.sc.com.my)

For companies with activities comprising both permissible and non-permissible activities, the SAC of SC measures level of mixed contributions from permissible and non-permissible activities towards turnover and profit before tax of a company. The SAC of SC uses benchmarks based on legal reasoning method (Ijtihad). Where the contributions of nonpermissible activities exceed the benchmark, the securities shall be classified as Shariah noncompliant. The SAC of SC subsequently assesses the financial management of the company by applying financial ratio benchmarks. The financial ratio benchmarks are intended to measure riba and riba-based elements within a company's statements of financial position.

\section{Preservation of Life}

Second is the preservation of life by avoiding from any form of equities funds with stocks in tabacco, gaming and others which can be harmful to the society life, even if it generates long term capital growth and consistent income and return to investors. This is including equity funds that invest in weapons products and which can threaten human and natural life. Other than that, the Islamic equity funds should increase investments that lead to the improvement quality of life of the society in which the equity is directly involved in allocating public infrastructure and facilities, as well as increase in profits and return to investors. Hence, providing the Islamic equity funds by government or private sector is the value added as a preservation of life for strengthening the development of Muslim life. Allah S.W.T said: "And spend of your substance in the cause of Allah and make not your own hands contribute to (your) destruction; but do good; for Allah loved those who do goodness". (Al-Quran: AlBaqarah: 2; 90). In addition, the life cycle of the Islamic equity funds products offered will also be considered to ensure that profitability and good returns can be given to investors if it does not conflict with the Shariah principles. 


\section{Preservation of Intellect}

The next is the preservation of intellect. Therefore, any Islamic equity funds development cannot be investing in any form of activity that involves any sense of deception such as the manufacture of intoxicants or liquor and others. Allah SWT said: "O ye who believe! Intoxicants and gambling, (dedication of) stones, and (divination by) arrows, are an abomination, - of Satan's handwork: eschew such (abomination), that ye may prosper". (AlQuran: Al-Maaidah; 5: 90). Equity fund offerings also need to emphasize investments in the education sector which can enhance the knowledge of the community as well as the high profits earned from the investment activities. As for investors, they need to emphasize on enhancing knowledge for every investment in Islamic equity fund in order to avoid from any form of fraud and injustice. Hence, every investor needs to be given due diligence and learning process in Islamic equity funds to get more profitable investment as well as Shariahcompliant. Allah SWT said: "Are those equal, those who know and those who do not know? It is those who are endued with understanding that receive admonition". (Al-Quran: Az-Zumar; 39: 9)

\section{Preservation of Progeny}

The development of Islamic equity fund products should also take into consideration the chain of companies offering the products, including in the preservation of progeny. This is to ensure the continuity of the company to remain competitive and directly increase the value of the Islamic equity funds offered. Investment in these funds can also help to protect the progeny of an investor so that returns can be used for that purpose. Through this concept, investment in the Islamic equity fund can be inherited to its offspring and this has a positive impact on economic growth in which the wealth chain can be inherited to the families.

\section{Preservation of the Wealth}

The development of Islamic equity funds should also consider the profitability by ensuring the competitiveness and effectiveness of Islamic equity funds industry. Hence, the preservation of the wealth is a necessity for the sustenance revenue with permissible (halal) services and received the blessings of Allah SWT. This shows that Islamic equity funds need to be expanded to attract more Muslim and non-Muslim investors in promoting halal products and services in the world market as generating wealth and productivity for a country. With generating wealth and profits earned from Islamic equity funds, then the value of paid zakat will increase, and the outcome will be used for distribution purposes to the needy and poor society in order to reduce the poverty gap in the community system for the public interest (maslahah). Therefore, one of the main objectives (maqasid) is upon public welfare (maslahah), which is in line with one of the principles of legal maxims (qawa id alfiqhiyyah) which states "management of citizen's affairs is depended upon public welfare" (al-tasarruf 'ala al-ra 'iyyati manutu bi al-maslahah). (Zuhaili, 1996). The objective of all those legal rulings is for the preservation of religion that is to avoid poverty and ingratitude in society. Hence, the preservation of the wealth is to ensure the circulation of wealth among members of the society level could be equally distributed. This coincides with the Qur'anic verse, which Allah (swt) says: "so that it may not be [a benefit] going around and around among such of you as may [already] be rich”. (Al-Quran: Al-Hasyr; 59: 7)

\section{Conclusion}

In conclusion, the development of Islamic equity funds should be in line with the Maqasid Shari'ah perspective as sustainable of financial planning which bring to the social well-being and impartiality for the public interest (maslahah). Therefore, the development of Islamic 
equity fund products is falls under the category of public interest (maslahah) by taking into consideration of five preservation, namely the preservation of religion (al-ddin), the preservation of life (al-nafs), the preservation of intellect (al-'aql), the preservation of progeny (al-nasl) and the preservation of wealth (al-mal). (Mohamed Fisol, Ariffin. \& Ismail Mat 2017). Hence, this conclusion can be demonstrated through the following table 3 below:

Table 3: Islamic Equity Funds Based on the Maqasid Shari'ah Framework

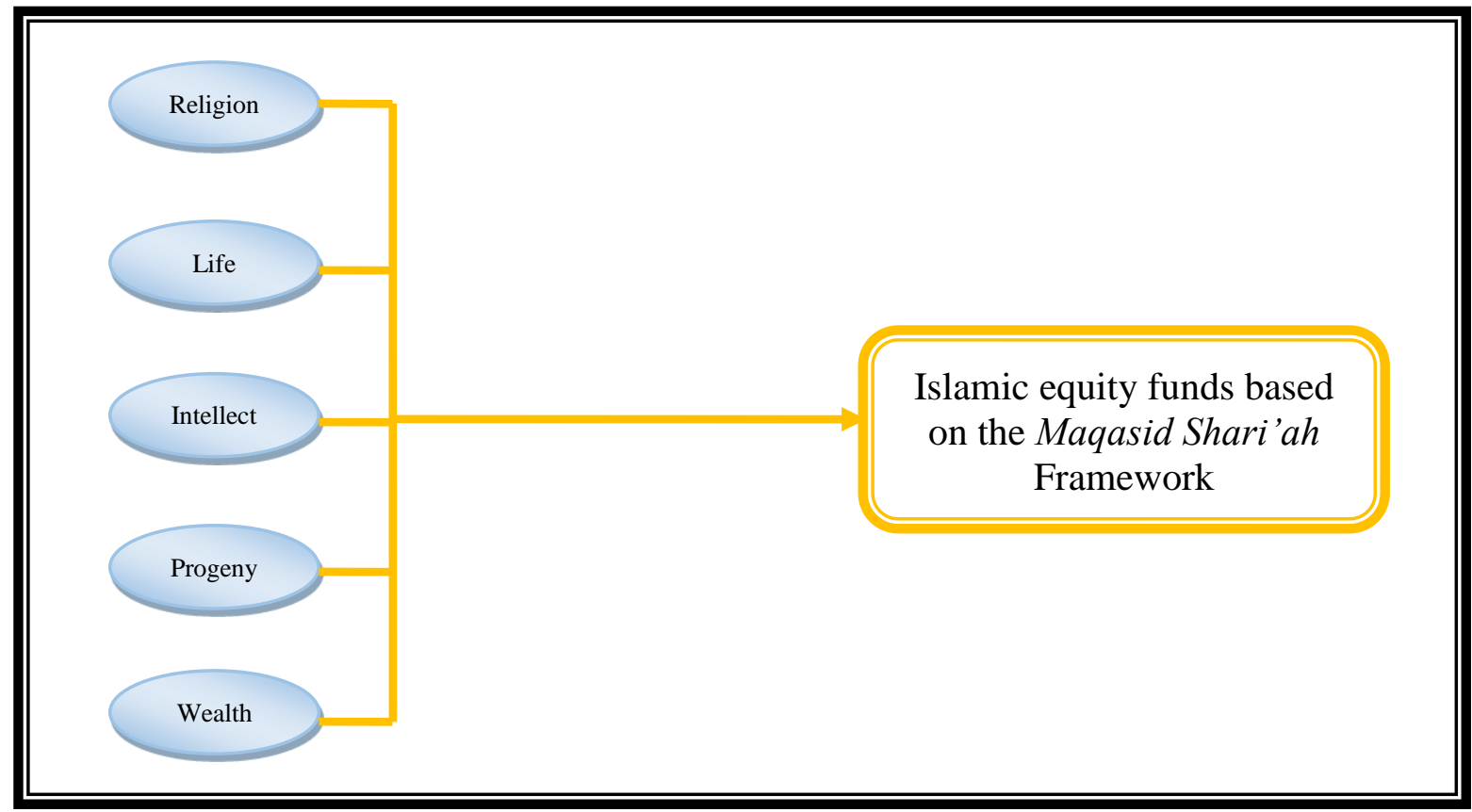

\section{References}

Abdullah, F., Hassan, T., \& Mohammad, S. (2007). Investigation of Performance of Malaysian Islamic unit trust funds. Journal of Managerial Finance, 33(2),142-153.

Abd. Rahman, Z. (2014). Maqasid al-Shari'ah fi Ahkam al-Buyu'-Fiqh Kewangan Islam. Malaysia. PTS Islamika Sdh. Bhd.

Ahmed, H. (2011). Maqasid Al-Shari'ah and Islamic Financial Products: A Framework for Assessment. Kuala Lumpur: ISRA International Journal of Islamic Finance. Vol. 3, Issue 1.

Al-Qaradawi, Y. (2011). Fiqh al-Awlawiyyat. Ed. Abu Amal Ghafar. Fiqh Keutamaan. Perniagaan JahaBersa; Malaysia.

Al-Ghazali, M. (1998). al-Mustasfa min 'ilm al-usul. Beirut: Dar al-Kutub al-'Islamiyyah.

Al Rafai, T. (2000). Monitoring the performance of Islamic equity funds. New Horizon (103), 6-11

Cebeci, I.(2012). Integrating the social maslahah into Islamic finance. Accounting Research Journal Vol. 25 No. 3, 2012 pp. 166-184 @ Emerald Group Publishing Limited 10309616 DOI 10.1108/10309611211290158

Chapra, M. U. (2009). The Islamic of Development in the Light of the Maqasid al-Shariah. The 1st Insaniah-IRTI International Conference on Islamic Economics, Financial 2009.

Dusuki, A. W. \& Abdullah, N. I. (2007). Maqasid al-Shari'ah, Maslahah, and Corporate Social Responsibility. The American Journal of Islamic Social Sciences 24:1.

http://www.islam.gov.my/e-jakim/e-quran/terjemahan-al-quran

https://www.sc.com.my 
Mohamed Fisol, W. N., Md. Radzi, N. Z., Haji-Othman, Y. (2017). The Engineering of Islamic Legal Opinion (Ijtihad) On the Maqasid Al-Shari 'ah Development in the Assessment of Islamic Financial Products. International Journal of Academic Research in Business and Social Sciences. 7(4), 945-956.

Mohamed Fisol, W. N., Ariffin, M. S., Ismail Mat. (2017). The Issues in Islamic Financial Products: Based on the Scientific Maqasid Al-Shari 'ah Perspective. International Journal of Academic Research in Business and Social Sciences. 7(6) 979-990.

Shatibi, A. I. I (1997). Al-Muwafaqat, ed. 'Abu 'Ubaidah Mashhur. 7 Vols. Beirut: Mauqi' alMaktabah al-Raqmiyyah.

Tantawi, M. S. (1998). Al-Tafsir al-Wasit li al-Quran al-Karim. Qaherah: Dar al-Nahdah. Maktabah al-Shamilah. Vol.1.pp. 3429

Zaydan. A. K. (2002). Al-Madkhal li Dirasat al-Shariah al-Islamiyyah.6th ed. Beirut: Muassasah al-Risalah.

Zuhaili, W. (1996). Usul al-Fiqh al-Islami, Vol.2, Damascus: Dar al-Fikr, pp.1017 